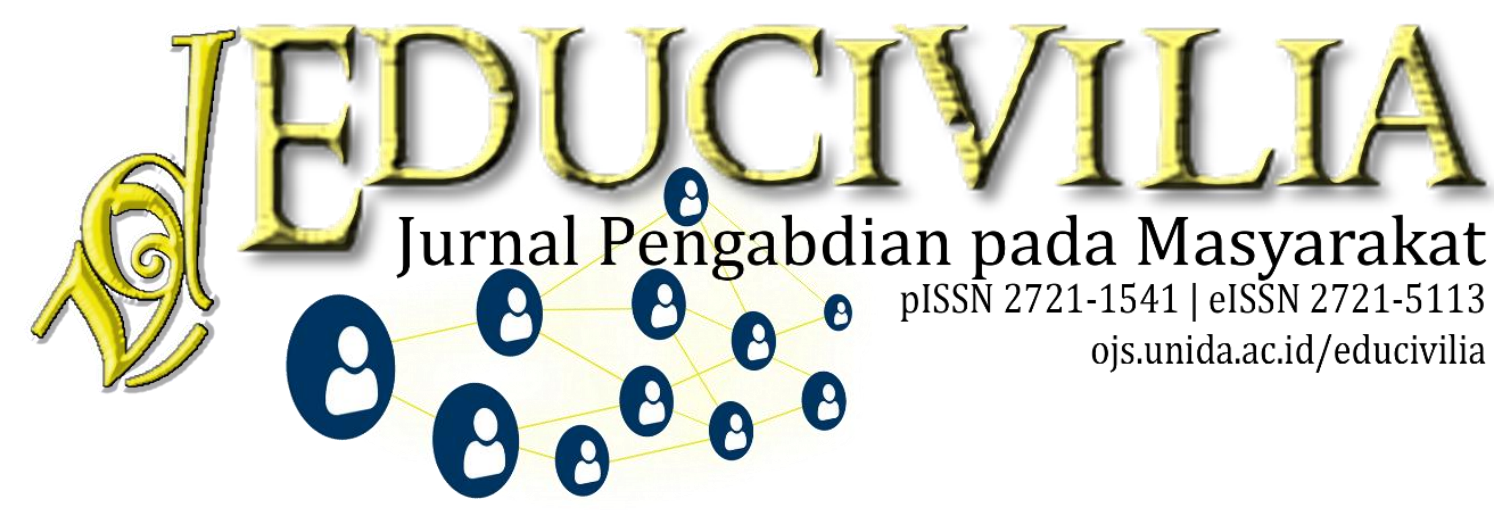

\title{
Pelatihan Penggunaan Perangkat Berbasis Internet dalam Pengumpulan Data Penelitian Masa Pandemi COVID-19
}

\author{
Lala Laila Zulfa, Euis Mauna Mujibah, Zahra Fitrah Rajaguguk \\ Program Studi Pendidikan Guru Sekolah Dasar, Fakultas Keguruan dan Ilmu Pendidikan \\ Universitas Djuanda, Jl. Tol Ciawi No. 1 Kontak Pos 35 Ciawi Bogor 16720
}

\begin{tabular}{l} 
Kilas Artikel \\
\hline Volume 1 Nomor 2 \\
Juli 2020: 143-158 \\
DOI: 10.30997/ejpm.v1i2.2835 \\
Article History \\
Submission: 11-06-2020 \\
Revised: 09-07-2020 \\
Accepted: 14-07-2020 \\
Published: 23-07-2020 \\
Kata Kunci: \\
Pembelajaran daring, Covid-19, \\
Workshop, pengumpulan data. \\
Keywords: \\
Online learning, Covid-19, \\
Workshop, Data Collection. \\
Korespondensi: \\
Lala Laila Zulfa \\
(lailazulfa24@gmail.com)
\end{tabular}

PENDAHULUAN

Pandemi Covid-19 berdampak pada seluruh sektor tatanan kehidupan

\begin{tabular}{l} 
Abstrak \\
\hline Pemberlakuan Physical Distancing pada masa pandemi COVID-19 \\
membuat keadaan menjadi terbatas. Seluruh sekolah dan perguru- \\
an tinggi dialihkan untuk belajar di rumah dan melaksanakan pem- \\
belajaran daring (dalam jaringan). Pengabdian masyarakat ini ber- \\
tujuan untuk memberikan kompetensi mahasiswa PGSD dalam \\
strategi metodologi pengumpulan data penelitian pada era digi- \\
talisasi. Pelaksanaan webinar berbentuk workshop via internet de- \\
ngan aplikasi tatap muka Zoom. Pandemi Covid-19 tetap memaksa \\
mahasiswa untuk melaksanakan pengumpulan data sebagai bahan \\
penyusunan skripsi. Hasil pengabdian masyarakat ini mengung- \\
kapkan pengumpulan data merupakan insrumen yang begitu pen- \\
ting dalam penelitian skripsi, era digitalisasi mendorong mahasiswa \\
semester akhir melaksanakan pengumpulan data secara digital de- \\
ngan aplikasi berbasis internet. Proses perencanaan dan persiapan \\
pelaksanaan workshop pengabdian masyarakat harus dipersiapkan \\
dengan sebaik mungkin. \\
\hline Training in Using Internet Based Devices in COVID-19 Pandemic \\
Period Research Data Collection \\
Abstract \\
\hline The implementation of Physical Distancing during the co-19 pandemic \\
made the situation limited. All schools and colleges are diverted to study at \\
home and carry out online learning (in the network). This community \\
service aims to provide PGSD student competencies in research \\
methodology strategies in the digitalization era. The webinar is in the form \\
of a workshop via the internet with a Zoom face-to-face application. The \\
results of this community service reveal that research is a very important \\
instrument in preparing a thesis, the era of digitalization encourages \\
students in the final semester to conduct research digitally. The planning \\
and preparation process must be prepared as well as possible. \\
\hline
\end{tabular}

Indonesia dan seluruh dunia. Terutama dalam dunia pendidikan, seluruh sekolah dan perguruan tinggi dialihkan un- 
tuk belajar di rumah dan melaksanakan pembelajaran daring (dalam jaringan) sesuai dengan anjuran Menteri Pendidikan dan Kebudayaan (MENDIKBUD) dalam Surat Edaran (SE) Nomor 4 Tahun 2020 tanggal 24 Maret 2020 dan memperhatikan Surat Keputusan Kepala Badan Nasional Penanggulangan Bencana Nomor 13 A Tahun 2020 tentang Perpanjangan Status Keadaan Tertentu Darurat Bencana Wabah Penyakit Akibat Virus Corona di Indonesia (Yanti, M. T., Kuntarto, E., \& Kurniawan, 2020).

Karakter berjuang dan pantang menyerah idealnya dimiliki mahasiswa sebagai agen perubahan. Wabah Covid19 telah banyak membuat situasi menjadi sulit. Berdampak juga pada mahasiswa tingkat akhir yang mengalami kesulitan menyelesaikan skripsi diakibatkan pandemi ini mendera Indonesia sejak awal Maret 2020. Banyak tahapan dalam membuat karya ilmiah ini, salah satu dalam penyusunannya yaitu melibatkan penelitian lapangan (Nurhalimah, 2020). Pemberlakuan Physical Distancing membuat keadaan menjadi terbatas, namun hal tersebut tidak menghalangi para mahasiswa untuk tetap melaksanakan penelitian demi memper-oleh gelar strata 1.

Rangkaian kegiatan edukasi seperti workshop, seminar, diskusi, mengadakan dan mengikutsertakan ajang lomba in-ternal dan eksternal serta kegiatan social relation lain yang berkaitan dengan masyarakat merupakan upaya dalam melatih dan meningkatkan kompetensi mahasiswa PGSD Djuanda Bogor. Program pengabdian masyarakat ini juga ber-tujuan untuk memberikan pelatihan kepada mahasiswa dalam menggunakan perangkat berbasis internet sebagai cara pengumpulan data penelitian skripsi.

Workshop penelitian pendidikan ini salah satu rangkaian acara yang telah dilaksanakan oleh Program Studi dan Himpunan Mahasiswa PGSD yang bertujuan untuk meningkatkan kualitas mahasiswa dalam pemahaman metode penelitian dan strategi penelitian di masa pandemi. Webinar ini sangat bermanfaat dan memberikan ilmu bagi mahasiswa yang belum mempelajarinya di bangku kuliah maupun sebagai review secara mendetail dengan pemateri yang ahli dibidangnya bagi 
Educivilia: Jurnal Pengabdian pada Masyarakat Volume 1 Nomor 2, Juli 2020

mahasiswa yang sudah mempelajarinya di kelas.

Masa pandemi COVID-19 dan era digitalisasi ini tidak menjadi hambatan besar lagi bagi para mahasiswa yang sedang menuntaskan tugas akhir skripsi (Nurhalimah, 2020). Peneliti harus bertindak cerdas dan kreatif agar penelitian tetap terlaksana dengan memanfaatkan teknologi dan internet. Keadaan pandemi tidak menyurutkan semangat kita dalam mendapatkan ilmu pengetahuan. Workshop ini sangat bermanfaat bagi mahasiswa yang sedang melakukan penelitian ataupun mahasiswa junior untuk mempersiapkan knowledge dan skill di masa yang akan datang. Manusia hidup di lingkungan yang selalu senantiasa berubah dan berkembang. Keberagaman lingkungan dan keunikan manusia menimbulkan kesulitan dan berbagai masalah yang bervariasi menuntut keadaan masing-masing. Penelitian (research) merupakan salah satu langkah untuk menyelesaikan satu masalah atau mencari jawaban dari kasus yang dihadapi secara keilmuan, memanfaatkan cara berpikir relaktif, berpikir ilmiah dengan
p-ISSN 2721-1541 | e-ISSN 2721-5113 || 145

DOI: $10.30997 /$ ejpm.v1i2.2835

sistem yang harus sesuai dengan tujuan dan sifat penyelidikan (Yusuf, 2016).

Menurut (Shuttleworth, 2008) dalam arti luas research dimaknai sebagai pengumpulan data, fakta dan informasi untuk perkembangan pengetahuan. Pada dasarnya, metodologi penelitian mempunyai peranan yang begitu penting dalam penyusunan skripsi, metode penelitian yang digunakan dalam penelitian tersebut diarahkan untuk melancarkan peneliti dalam menulis skripsinya. Kehadiran era digitalisasi tidak dapat dihindari lagi, Indonesia harus menyiapkan langkah-langkah strategis agar dapat beradaptasi dengan era digitalisasi ini (Eka \& Wuryanta, 2013).

\section{METODE}

Metode yang digunakan dalam pengabdian masyarakat ini yaitu workshop. Metode ini dipilih karena sangat cocok dengan program pengabdian masyarakat ini yang memberikan pelatihan dengan penggunaan aplikasi berbasis internet untuk pengumpulan data penelitian.

Canggihnya media teknologi mendukung gagasan baru dalam seluruh 
bidang, khususnya dalam dunia pendidikan. Webinar merupakan istilah dari kata web dan juga seminar yang artinya seminar dengan menggunakan website atau internet (Verma, A., \& Singh, 2010). Webinar sebagai solusi atas kebutuhan pertemuan secara tatap muka bagi pemateri dan peserta secara jarak jauh seperti masa Physical Distancing sekarang ini. Definisi webinar adalah sebuah seminar, presentasi atau workshop yang dilaksanakan secara online atau daring (dalam jaringan) disampaikan melalui internet dengan berbagai aplikasi media yang digunakan dan banyak orang yang menghadiri dari lokasi yang berbeda-beda. Peserta dapat berinteraksi langsung melalui video atau teks chatting (Prawira, 2019).

Webinar dilaksanakan online via ZOOM, oleh sebab itu peserta harus mengunduh terlebih dahulu aplikasi tersebut. Pendaftaran webinar ini sangat mudah untuk diikuti, peserta melakukan registrasi pada link google form yang sudah disediakan dengan mengisi nama lengkap, semester, nomer telepon dan alamat email. Setelah itu, akan dikirimkan alamat Meeting ID ZOOM, Password, dan link grup Whats- app via email. Oleh karena itu, diharapkan peserta mengirim alamat e-mail dengan benar. Pendaftaran ini gratis, tidak dimintai biaya apapun dan peserta mendapatkan fasilitas berupa ilmu bermanfaat dan e-sertifikat.

Peserta dapat mengikuti workshop webinar ini dengan cara join meeting dan memasukkan nomor ID dan password sesuai dengan waktu yang sudah disepakati yaitu Selasa, 02 Juni 2020 Pukul 08.00 WIB sampai dengan Pukul 12.00 WIB. Selama proses webinar berlangsung, peserta diharapkan mendengarkan pemaparan yang disampaikan narasumber dan mematikan (mute) audio agar tidak ada suara selain narasumber dan moderator. Sesi pertama adalah penyampaian materi dan sesi kedua adalah tanya jawab. Peserta dipersilakan bertanya terkait materi yang telah disampaikan. Pada akhir workshop akan ada doorprize bagi peserta yang dapat menjawab pertanyaan dengan tepat.

Dalam meningkatkan mutu serta kuantitas peserta webinar diperlukan sebuah strategi pemasaran yang kompeten. Fungsi pemasaran tidak hanya memberikan suatu citra saja, akan tetapi akan memberikan nilai nuansa keun- 
tungan bagi bersama (Febriani, N. S., \& Dewi, 2018). Sejalan dengan itu, upaya promosi yang dilaksanakan adalah dengan memposting pamflet dan broadcast di beberapa akun sosial media seperti Instagram, Whatsapp, dan blog website.

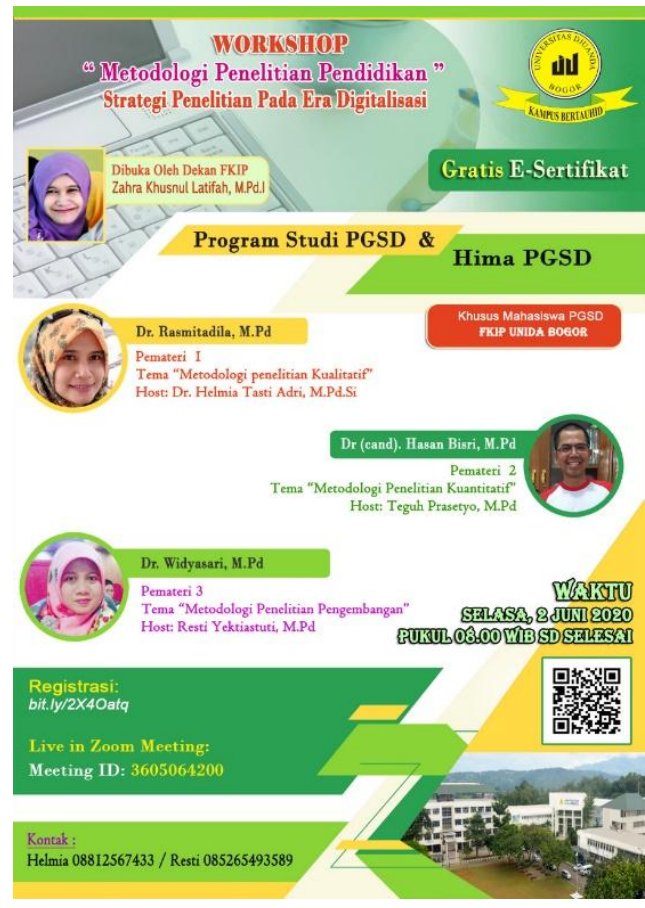

Gambar 1 Pamflet

HASIL \& PEMBAHASAN

Webinar dilaksanakan pada hari Selasa tanggal 02 Juni 2020 Pukul 08.00 WIB sampai dengan pukul 12.00 WIB dengan tema workshop Metodologi Penelitian Strategi Penelitian Pada Era Digitalisasi diselenggarakan oleh Program Studi dan Himpunan Mahasiswa PGSD. Workshop ini diikuti oleh Mahasiswa PGSD Fakultas Keguruan dan Ilmu Pendidikan Universitas Djuanda Bogor dari
p-ISSN 2721-1541 | e-ISSN 2721-5113 || 147

DOI: 10.30997/ejpm.v1i2.2835

semester 4 hingga semester 8 . Jumlah peserta webinar berjumlah 90 orang dari batas jumlah peserta 100 orang. Promosi penyebaran informasi pelaksanaan webinar dilakukan melalui pamflet dan broadcast yang disebar pada akun sosial media Instagram, Whatsapp dan blog.

Acara ini dibuka oleh Zahra Khusnul Lathifah, M. Pd. I selaku Dekan Fakultas Keguruan dan Ilmu Pendidikan. Pemateri Pertama disampaikan oleh Dr. Rasmitadila, M. Pd dengan tema materi Metodologi Penelitian Kuantitatif yang dimoderatori oleh Dr. Helmia Tasti Adri, M. Pd.Si. Pemateri Kedua disampaikan oleh Dr (cand). Hasan Bisri, M. Pd dengan tema materi Metodologi Penelitian Kuantitatif dan ditemani oleh Teguh Prasetyo, M.Pd sebagai moderator. Pemateri terakhir oleh Dr. Widyasari, M. Pd dengan tema materi Metodologi Penelitian Pengembangan dan ditemani oleh Resti Yektiastuti, M. Pd sebagai moderator.

\section{Metodologi Penelitian Kualitatif}

Penelitian kualitatif adalah sebuah riset atau penelitian yang bersifat deskriptif dan analisis yang mengarah pada pendekatan induktif. Dalam 
pandangan riset kualitatif, fenomena dari suatu objek itu dapat dikatakan bersifat holistik yaitu menyeluruh tidak dapat dipisahkan, sehingga seorang peneliti kualitatif tidak dapat menentukan penelitiannya hanya bersumber pada variabel penelitian, akan tetapi keseluruhan keadaan sosial yang diteliti meliputi segi tempat, pelaku dan kegiatan yang berinteraksi secara berkesinambungan. Situasi sosial ini di dalam kelas seperti ruang kelas, guru, murid dan kegiatan belajar mengajar (Sugiyono, 2014). Penelitian Kualitatif dilakukan dengan karakteristik yang memberikan deskripsi suatu keadaan yang sebenarnya, laporan yang dibuat bukan sekedar laporan suatu kejadian tanpa suatu penjelasan ilmiah. Penelitian Kualitatif tidak menggunakan statistik, tetapi melalui pengumpulan data, analisis kemudian diinterpretasikan.

Beberapa jenis dan karakteristik metode kualitatif menurut Jacob dan Creswell. Jacob (Raco, 2018) memaparkan 6 jenis metode kualitatif, yaitu Etologi Manusia (Human Ethology), Etnologi Holistik (Holistic Ethnography), Antropologi Kognitif (Cognitive Anthropology), Ethnography Komuni- kasi (Etnography Communication), Interaksi Simbolik (Simbolic Interaction) dan Psikologi Lingkungan (Ecology Psycho$\log y)$.

Etologi Kemanusiaan atau Human Ethology adalah suatu metode yang memiliki tujuan untuk mempelajari tingkah laku manusia secara alamiah. Perilaku manusia selalu berkembang dan dinamis dipengaruhi lingkungan. Namun diyakini bahwa ada perilaku bawaan sejak lahir (inborn) yang akan selalu menetap dan tidak terpengaruh oleh perubahan lingkungan. (Semiawan, 2010) Ada pula tingkah laku manusia yang selalu menerima atau perilaku turunan (innate) dan selalu berubah menyesuaikan dengan keadaan situasi dan kondisi lingkungan sekitarnya.

Etnologi Holistik bertujuan mempelajari kebudayaan secara utuh. Asumsinya yaitu kebudayaan terkait dengan faktor-faktor lain seperti ekonomi, politik, sejarah, sosial dan teknologi. Oleh sebab itu, untuk mengerti suatu budaya secara kompleks harus memiliki pemahaman dengan kondisi yang berlaku pada zamannya (Fitrah, 2018). 
Educivilia: Jurnal Pengabdian pada Masyarakat Volume 1 Nomor 2, Juli 2020

Antropologi Kognitif yaitu menekankan bahwa budaya muncul berasal dari pengetahuan manusia (Keesing, 2014). Penciptaan kebudayaan diawali dengan persepsi, naluri dan pikiran manusia yang kemudian menurunkan perilaku, norma hidup, tatakrama dan gagasan hidup bersama. Pada dasarnya, seluruh budaya material yang telah dihasilkan manusia itu hasil dari pemikiran manusia dalam berinteraksi dan membentuk suatu makna dalam kehidupan sosial.

Etnografi Komunikasi berasumsi bahwa manusia menemukan diri yang berbeda tidak seperti yang lain (Gunawan, 2017). Perbedaan ditandai dengan perbedaan umur, status, pendidikan, latar belakang etnik, pengalaman, jenis kelamin, agama, lingkungan dan peran masyarakat. Semua dampak yang ditimbulkan oleh pemakaian bahasa akan dipelajari dalam kerangka etnografi komunikasi ini.

Interaksi Simbolik menegaskan bahwa interaksi sosial di masyarakat adalah sebagai ungkapan interaksi simbolik. Inti dari metode ini adalah mengungkapkan bagaimana cara manusia dalam menggunakan simbol-simbol
p-ISSN 2721-1541 | e-ISSN 2721-5113|| 149

DOI: 10.30997/ejpm.v1i2.2835

dalam mengekspresikan apa yang akan disampaikan dalam proses komunikasi. Karena relasi komunikasi antar manusia selalu menggunakan simbol-simbol yang ditangkap dan dimengerti bersama (Siregar, 2012).

Psikologi Lingkungan yaitu metode yang digunakan untuk mempelajari hubungan perilaku manusia terhadap lingkungannya (Maslihah, 2011). Manusia berperan dalam merubah lingkungannya dan sebaliknya bahwa lingkungan turut mempengaruhi dan merubah manusia. Tujuan utama metode ini adalah memahami tingkah laku manusia yang dipengaruhi oleh lingkungan fisiknya (Semiawan, 2010).

(Cresswell, 1998) menyatakan terdapat lima macam metode penelitian kualitatif yaitu Biografi, Fenomenologi, Grounded-Theory, Etnografi dan Studi Kasus. Pertama, jenis metode Biografi istilah lainnya yaitu Narasi Personal, Sejarah Lisan dan Otobiografi. Metode Biografi merupakan suatu metode penelitian yang berusaha menghadirkan sejarah kehidupan seseorang serta dapat memberikan manfaat bagi pembaca. Metode ini biasanya disusun berdasarkan kisah pengalaman seseo- 
rang atau orang itu sendiri, dokumen maupun arsip lain yang tersimpan.

Kedua yaitu metode Fenomenologi, dasar teoritis metode ini adalah filsafat fenomenologi. Fenomenologi mendefinisikan suatu fenomena dan maknanya bagi perseorangan dengan melakukan wawancara. Kemudian temuan ini dikaitkan dengan prinsipprinsip filosofis fenomenologi. Studi ini diakhiri dengan hakikat dari makna. Fenomenologi berasumsi bahwa setiap individu mengalami fenomena dengan segenap kesadarannya (Hasbiansyah, 2008). Tujuan dari metode ini yaitu untuk mengungkapkan esensi secara universal dari fenomena yang dialami secara individu oleh suatu kelompok masyarakat.

Ketiga yaitu Grounded-theory, merupakan metode kualitatif dengan tujuan menemukan teori baru. Ilmu-ilmu sosial dan metodologi digunakan sebagai dasar dari metode ini. Teori apa yang muncul sesudah analisa data lapangan dilaksanakan adalah perta-nyaan utama yang hendak dijawab. Memakai analisis induktif karena hendak menemukan teori baru (Gunawan, 2013).
Metode yang keempat yaitu etnografi, asumsi dasar dari metode ini adalah manusia yang hidup bersama selalu menjadi hubungan dengan manusia lain. Interaksi yang dilakukan manusia pada jangka yang panjang akan membentuk suatu budaya. Tujuan utama metode ini adalah memahami pengalaman hidup manusia (Sarmanu, 2017). Hal ini didasarkan pada beberapa pandangan seperti realita bersifat jamak, tatanan sosial budaya terbentuk oleh budaya yang dianutnya, manusia menciptakan makna melalui interaksi dengan manusia lain, tindakan seseorang akan memberikan pengaruh terhadap orang lain dan keberadaan manusia bersifat dinamis.

Jenis metode yang kelima adalah Studi Kasus, Creswell mendefinisikan studi kasus sebagai suatu eksplorasi dari sistem-sistem yang terkait atau kasus. Suatu kasus menarik untuk diteliti karena memiliki khas kasus yang memberikan arti pada orang lain khususnya penulis. Bentuk studi kasus dapat berupa deskriptif, eksplorasi dan eksplanatori.

Masa Pandemi dan era Revolusi 4.0 ini membangun digitalisasi dalam du- 
Educivilia: Jurnal Pengabdian pada Masyarakat Volume 1 Nomor 2, Juli 2020

nia penelitian (Suwardana, 2018) dengan strategi-strategi yaitu: 1) Jaringan internet memungkinkan peneliti mengumpulkan informasi dari responden yang berada jauh di belahan bumi yang lain; 2) Survei daring bisa mengumpulkan dan menampilkan ringkasan data dalam skala besar; 3) Karakteristik rekaman gawai cerdas dipakai untuk merekam wawancara, dan 4) Perangkat lunak sistem informasi secara luas telah dipakai untuk mengumpulkan, memperlihatkan dan menganalisis data spasial dan geografi.

Proses pengumpulan data merupakan langkah yang paling pokok dalam penelitian, karena penelitian bertujuan untuk mendapatkan data. Tanpa mengetahui teknik pengumpulan data, maka peneliti tidak akan memperoleh data yang mencu-kupi standar data yang ditetapkan (Bachri, 2010). Teknik Pengumpulan Data Kualitatif di era digital dapat dilakukan beberapa cara yaitu, wawancara dilakukan secara tertulis atau menggunakan video konferensi, Penggunaan artikel dari jurnal akses terbuka maupun berbayar, Pengamatan terhadap situasi dan subjek penelitian dapat dilakukan secara cermat
p-ISSN 2721-1541 | e-ISSN 2721-5113|| 151

DOI: 10.30997/ejpm.v1i2.2835

dengan memutar ulang rekaman video dan dapat dilakukan Focus Group Discussion (FGD) secara daring.

\section{Metodologi Penelitian Kuantitatif}

Penelitian kuantitatif adalah serangkaian kegiatan pengolahan, pengumpulan, analisis dan penyajian data berdasarkan jumlah yang dilaksanakan secara objektif untuk mengatasi suatu masalah atau menguji suatu premis untuk menguraikan prinsip-prinsip umum (Duli, 2019). Cohen dan Manion menyatakan bahwa penelitian kuantitatif adalah penelitian sosial yang menggunakan metode-metode dan pernyataan-pernyataan empiris. Pernyataan empiris merupakan pernyataan deskriptif tentang "apa itu kasus" di "dunia nyata" dari apa yang "seharusnya" terjadi. Biasanya pernyataan-pernyataan empiris dinyatakan dalam bentuk angka.

Penelitian kuantitatif umumnya berfokus pada pengukuran realitas sosial. Penelitian kuantitatif dirancang melalui pernyataan (kuesioner) atau pertanyaan untuk mencari kuantitas pada suatu fenomena dan untuk membangun penelitian secara numerik. Peneliti kuantitatif memandang dunia 
sebagai kenyataan yang dapat ditentukan secara objektif sehingga panduan yang ketat terhadap proses pengumpulan serta analisis data sangat penting (Yusuf, 2016). Penelitian kuantitatif dapat diklasifikasikan ke dalam beberapa jenis, yang pertama Penelitian Survei, tujuan utamanya adalah mengumpulkan tentang informasi variabel dari sekelompok objek (populasi). Survei dengan lingkup seluruh objek disebut sensus. Adapun yang menganalisis hanya sebagian objek disebut dengan sampel survei. Survei dapat dilakukan untuk mengetahui variabel seperti persepsi orang, argumentasi, tingkah laku, prestasi dan motivasi. Survei adalah metode riset yang digunakan untuk menyelesaikan masalah sesuai dengan pertanyaan yang sudah diajukan atau sesuai masalah yang diamati. Penelitian survei menggunakan pengambilan sampel ilmiah dan desain kuesioner untuk mengukur karakteristik populasi dengan ketepatan statistik.

Kedua, Penelitian Korelasional adalah penelitian non-eksperimen yang dipastikan tidak dapat mengkonfirmasi suatu hubungan kausal, meskipun da- pat digunakan untuk mengeksplorasi hubungan-hubungan kasual yang kompleks. Penelitian ini memberikan sudut pandang baru untuk memahami hubungan-hubungan dan serangkaian alat analitik baru untuk menghitung dan membuat perkiraan tentang suatu hubungan sebab-akibat (Burhan, 2019). Inilah suatu bentuk penelitian noneksperimental yang menggunakan korelasi statistik untuk mengeksplorasi keterkaitan antara variabel-variabel di dalam suatu kelompok sasaran.

\section{Ketiga, Penelitian Eksperimental} merupakan metode pokok dari metode penelitian kuantitatif (Hamdi, A. S., \& Bahruddin, 2015). Dalam penelitian eksperimental, peneliti harus merumuskan variabel minimal satu dugaan/hipotesis yang mengemukakan hubungan sebab akibat diantara variabel yang ada. Desain penelitian eksperimental meliputi hipotesis, variabel yang dapat dimanipulasi oleh peneliti dan variabel yang dapat dihitung, diukur dan dibandingkan. Penelitian eksperimental bertujuan untuk menentukan hubungan antara dua variabel, yaitu variabel dependen dan variabel independen. 
Educivilia: Jurnal Pengabdian pada Masyarakat Volume 1 Nomor 2, Juli 2020

Keempat, Penelitian Kasual-Komparatif berupaya mengidentifikasi hubungan kausatif antara variabel independen dan variabel dependen atau hubungan sebab akibat untuk menganalisis kemungkinan keterkaitan sebabakibat dengan cara bersumber dari pengamatan terhadap pengaruh yang ada dan menyelidiki kembali faktor yang mungkin menjadi penyebab tersebut melalui data tertentu. Definisi dari studi kasus adalah studi yang berusaha mengamati alasan atau penyebab terjadinya sebuah fenomena yang diteliti. Ciri-ciri praktik riset kuantitatif adalah Menguji atau memverifikasi teori, mengidentifikasi variabel yang diteliti, menghubungkan variabel dalam rumusan masalah dan hipotesis, menggunakan standar validitas dan reliabilitas, pengukuran secara numerik, obyektif dan menerapkan prosedur statistik (Hadi, 2015).

Validitas riset terbagi menjadi dua, yaitu validitas internal dan validitas eksternal. Validitas internal mengacu pada apapun manipulasi dari variabel independen (treatment) benar-benar menyebabkan pengaruh yang dapat diobservasi pada variabel dependen,
p-ISSN 2721-1541 | e-ISSN 2721-5113 || 153

DOI: 10.30997/ejpm.v1i2.2835

bukan faktor yang lain sedangkan validitas eksternal berkaitan dengan generalisasi hasil penelitian eksperimen yaitu sejauh mana generalisasi hasil riset pada populasi (Hendryadi, 2017).

Faktor-faktor yang berpengaruh pada validitas internal meliputi sejarah (history), kematangan (maturitas), seleksi (selection), prosedur tes (learning effect), instrumen (instrumentation), mortalitas (mortality), regresi ke arah nilai rata-rata (regression toward the mean). Faktor-faktor yang berpengaruh pada validitas eksternal meliputi instrumen riset valid dan reliabel, sampel penelitian representatif, kaidah mengumpulkan dan menganalisis data benar.

\section{Penelitian pendidikan dan pengem- bangan (R \& D)}

Penelitian pendidikan dan pengembangan ( $R$ \& D) adalah suatu proses yang digunakan untuk mengembangkan serta memverifikasi produk pendidikan. Pendekatan penelitian dan pengembangan kerap disebut dengan research based development. Penelitian dan pengembangan ini tentu berbeda dengan penelitian pengembangan (developmental research) (Haryati, 2012). Borg and Gall (1983) mengartikan penelitian 
pengembangan adalah langkah-langkah dari rangkaian prosedur $\mathrm{R} \& \mathrm{D}$ yang disebut dengan siklus $R$ \& $D$, prosedur ini tersusun dari mengkaji temuan penelitian yang berhubungan dengan produk yang akan dikembangkan, mengembangkan produk berasumsi pada temuan, bidang pengujian dalam pengaturan yang akan digunakan nantinya dan peninjauan untuk memperbaiki kelemahan yang ditemukan dalam fase mengajukan pengujian (Yasa, 2012). Menurut Gay L. R. penelitian Pengembangan adalah suatu cara untuk mengembangkan suatu produk yang lebih efektif untuk memberdayakan, bukan sebatas untuk menguji teori saja (Sutarti, T., \& Irawan, 2017).

Berikut ini Karakteristik Penelitian pengembangan menurut I Wayan Santyasa, 2009 yaitu:

-Masalah yang ingin diuraikan adalah masalah konkret yang berkaitan dengan usaha inovatif atau sebagai penerapan implementasi dalam pembelajaran.

- Pengembangan desain, pendekatan, media belajar dan metode pembelajaran yang membantu keefektifan dalam mencapai kompetensi peserta didik.
- Proses pengembangan suatu produk, validasi yang dilakukan melalui tahap uji ahli, dan percobaan lapangan secara terbatas harus dilaksanakan agar produk yang dihasilkan berguna untuk peningkatan mutu pembelajaran.

- Proses pengembangan, validasi, dan uji coba lapangan tersebut seyogyanya dideskripsikan secara jelas, sehingga dapat dipertanggung jawabkan secara akademik. (Santyasa, 2009).

Macam-macam model pengembangan penelitian yaitu : 1) Model ASSURE, yaitu terdiri dari beberapa langkah, Langkah pertama dalam sebuah pembelajaran adalah Analyze learner (menganalisis peserta didik) yaitu mengidentifikasi serta menganalisis karakteristik peserta didik agar pembelajaran lebih terarah dan sistematis. Langkah kedua, State standard and objectives (menetapkan tujuan pembelajaran), menentukan standar-standar dan tujuan belajar secara spesifik Dalam menentukan tujuan pembelajaran dapat dilakukan dengan cara audience, behaveor, condition, dan degree. Langkah ketiga, Select strategies, technology, media and materials (memilih strategi, teknologi, media dan materi). Langkah keempat, 
Educivilia: Jurnal Pengabdian pada Masyarakat Volume 1 Nomor 2, Juli 2020

Require learner participation (partisipasi peserta didik). Langkah kelima, Require learner participation (partisipasi peserta didik). Langkah terakhir, Evaluate and revise (penilaian dan arahan lanjutan);

2) Model ADDIE yang terdiri dari beberapa langkah yaitu Analysis, Design, Development, Implementation and Evaluation; 3) Model Borg \& Gall yaitu menetapkan 10 langkah prosedural, yaitu: 1. Research and Information Collecting (melakukan penelitian dan pengumpulan informasi; 2. Planning (melakukan perencanaan); 3. Develop Preliminary Form of Product (mengembangkan bentuk awal produk); 4. Preliminary Field Testing (melakukan percobaan lapangan tahap awal); 5. Main Product Revision (melakukan revisi produk utama), berdasarkan saran dari hasil uji coba lapangan awal; 6. Main Field Testing (melakukan percobaan lapangan untuk produk utama). Tes/ penilaian tentang prestasi belajar pebelajar dilakukan sebelum dan sesudah proses pembelajaran; 7. Operational Product Revision (melakukan peninjauan produk operasional); 8. Operational Field Testing (melakukan percobaan lapangan terhadap produk final; 9. Final product
p-ISSN 2721-1541 | e-ISSN 2721-5113 || 155

DOI: 10.30997/ejpm.v1i2.2835

revision (melakukan peninjauan produk final); 10. Dissemination and implementtation (diseminasi dan implementasi), tahap akhir yaitu menyampaikan hasil pengembangan kepada para produsen yang profesional melalui pertemuan, menuliskan dalam bentuk jurnal, buku atau handbook. Mendistribusikan produk harus dilakukan setelah melalui quality control.

3) Model Walter Dick And Lou Carey, model pengembangan ini ada kesamaan dengan model Kemp, perbedaannya adalah ditambah pelaksanaan analisis pembelajaran bahwa terdapat tahap yang akan dilewati pada proses pengembangan dan perencanaan tersebut. Langkah tersebut yaitu analisis kebutuhan (menetapkan tujuan program atau produk yang akan dikembangkan), mengidentifikasi karakteristik awal pembelajar, menetapkan tujuan kinerja atau prestasi berdasarkan hasil identifikasi, mengembangkan tes/instrumen berdasar kan kriteria yang telah ditetapkan, mengembangkan strategi pembelajaran (secara spesifik untuk membantu pembelajaran untuk mencapai tujuan khusus), mengembangkan dan memilih bahan pembelajaran, 
merancang dan melakukan evaluasi formatif (dilaksanakan oleh pengembang selama proses, prosedur, program atau produk), melakukan revisi (revisi pada tujuh langkah pertama) dan evaluasi sumatif (untuk meningkatkan tingkat efektivitas program secara keseluruhan).

4) Model Alessi Dan Trollip, model ini tersusun dari tiga tahapan dan tiga atribut yang selalu ada dalam setiap tahap. Tiga tahapan tersebut adalah Planning (perencanaan), Design (rancangan) dan Development (pengembangan). Komponen atribut Model Alessi Dan Trollip ini mencakup : Standards (standar), Ongoing Evaluation (evaluasi berkelanjutan), dan Project management (manajemen proyek).

\section{SIMPULAN}

Penelitian merupakan proses pengambilan data sesuai dengan keadaan lapangan. Metodologi penelitian sangat penting untuk dipahami oleh mahasiswa guna sebagai salah satu rangkaian perolehan gelar strata 1 . Masa Pandemi di era digitalisasi tidak menyurutkan semangat para mahasiswa semester akhir untuk menyelesaikan tugas skripsi. Penelitian dapat dilakukan dengan strategi-strategi sesuai dengan pendekatan metodologi yang digunakan. Masa physical distancing membuat semua lingkup terbatas, namun penelitian dapat terlaksana dengan mengandalkan media digital sebagai tumpuan utama.

Pelaksanaan webinar ini membutuhkan persiapan dan perencanaan yang matang. Proses pemilihan topik, peralatan yang akan digunakan, promosi kegiatan webinar hingga dokumentasi harus disiapkan dengan sebaik mungkin agar tidak ada kesalahan teknis pada saat pelaksanaan berlangsung.

\section{DAFTAR PUSTAKA}

Bachri, B. S. (2010). Meyakinkan validitas data melalui triangulasi pada penelitian kualitatif. Jurnal Teknologi Pendidikan, 10(1), 46-62. Burhan, B. (2019). Metodologi Penelitian Kuantitatif Komunikasi, Ekonomi, dan Kebijakan publik serta ilmu-ilmu sosial lainnya. Jakarta : Kencana.

Cresswell, J. W. (1998). Qualitative inquiry and research design: Choosing among Five Traditions.

Duli, N. (2019). Metodologi Penelitian Kuantitatif (3-5). Yogyakarta : CV. Budi Utama.

Eka, A. G., \& Wuryanta, W. (2013). Digitalisasi Masyarakat: Menilik Kekuatan dan Kelemahan Dinamika Era Informasi Digital dan Masyarakat Informasi. Jurnal Ilmu Komunikasi, 131-142. 
Febriani, N. S., \& Dewi, W. W. A. (2018). Teori dan Praktis: Riset Komunikasi Pemasaran Terpadu. Kediri : Universitas Brawijaya Press.

Fitrah, M. (2018). Metodologi penelitian: penelitian kualitatif, tindakan kelas $\mathcal{E}$ studi kasus. Sukabumi : CV Jejak (Jejak Publisher).

Gunawan, I. (2013). Metode penelitian kualitatif. Jakarta : Bumi Aksara.

Gunawan, I. (2017). Indonesian Curriculum 2013: Instructional management, obstacles faced by teachers in implementation and the way forward. In 3rd International Conference on Education and Training (ICET 2017). Atlantis Press.

Hadi, S. (2015). Metodologi Riset. Yogyakarta : Pustaka Pelajar.

Hamdi, A. S., \& Bahruddin, E. (2015). Metode penelitian kuantitatif aplikasi dalam pendidikan. Yogyakarta: Deepublish.

Haryati, S. (2012). Research and Development (R\&D) sebagai salah satu model penelitian dalam bidang pendidikan. Majalah Ilmiah Dinamika, 37(1), 15.

Hasbiansyah, O. (2008). Pendekatan Fenomenologi: Pengantar Praktik Penelitian dalam Ilmu Sosial dan Komunikasi. Mediator: Jurnal Komunikasi, 9(1), 163-180. https:/ / doi.org/10.29313/mediato r.v9i1.1146

Hendryadi, H. (2017). Validitas isi: tahap awal pengembangan kuesioner. Jurnal Riset Manajemen Dan Bisnis (JRMB) Fakultas Ekonomi UNIAT, 2(2), 169-178.

Keesing, R. (2014). Teori-teori tentang Budaya. Antropologi Indonesia. Maslihah, S. (2011). Studi tentang hubungan dukungan sosial, penyesuaian sosial di lingkungan sekolah dan prestasi akademik siswa SMPIT Assyifa Boarding School Subang Jawa Barat. Jurnal Psikologi, 10(2), 103-114.

Nurhalimah, N. (2020). Upaya Bela Negara Melalui Sosial Distancing Dan Lockdown Untuk Mengatasi Wabah Covid-19 (Efforts to Defend the Country Through Social Distancing and Lockdown to Overcome the COVID-19 Plague). Available at SSRN 3576405.

Prawira, Y. (2019). WEBINAR SEBAGAI MEDIA BIMBINGAN KLASIKAL SEKOLAH UNTUK PENDIDIKAN SEKSUAL BERBASIS ONLINE. SSRN

Electronic Journal, 5(564), 1-19. https:/ / doi.org/10.4324/97813158 53178

Raco, J. (2018). Metode penelitian kualitatif: jenis, karakteristik dan keunggulannya. Jakarta : Grasindo.

Santyasa, I. W. (2009). Metode penelitian pengembangan dan teori pengembangan modul. Makalah disampaikan dalam pelatihan bagi guru-guru dan Dosen di Nusa Penida Klungkung.

Sarmanu. (2017). Dasar Metodologi Penelitian Kuantitatif, Kualitatif dan Statistika. Surabaya : Airlangga University Press.

Satya, V. E. (2018). Kajian Singkat Terhadap Isu Aktual Dan Strategis Strategi Indonesia Menghadapi Industri 4.0. Pusat Penelitian Badan Keahlian DPR RI, X(09), 19.

Semiawan, C. R. (2010). Metode penelitian kualitatif. Jakarta : Grasindo.

Shuttleworth, M. (2008). Definition of research Experiment Resources.

Siregar, N. S. S. (2012). Kajian Tentang Interaksionisme Simbolik. 
Perspektif, 1(2).

Sugiyono. (2014). Metode Penelitian

Pendidikan Pendekatan Kuantitatif,

Kualitatif, dan RED. Bandung :

Alfabeta.

Sutarti, T., \& Irawan, E. (2017). Kiat sukses meraih hibah penelitian pengembangan. Yogyakarta : Deepublish.

Suwardana, H. (2018). Revolusi Industri 4. 0 Berbasis Revolusi Mental. JATI UNIK: Jurnal Ilmiah Teknik Dan Manajemen Industri, 1(2), 102-110.

Verma, A., \& Singh, A. (2010). Webinar-Education through digital collaboration. Journal of Emerging Technologies in Web Intelligence, 2(2), 131-136.

Yanti, M. T., Kuntarto, E., \& Kurniawan, A. R. (2020).
Pemanfaatan Portal Rumah Belajar Kemendikbud sebagai Model Pembelajaran Daring di Sekolah Dasar. Adi Widya: Jurnal Pendidikan Dasar, 5(1), 61-68.

Yasa, G. A. (2012). (2012).

Pengembangan Bahan Ajar Online Mata Kuliah Micro Teaching dengan Model Borg \& Gall pada Program S1 Pendidikan Bahasa Inggris STKIP Agama Hindu Singaraja. Jurnal Ilmiah Pendidikan Dan Pembelajaran Ganesha, 1(1), 207-120.

Yusuf, A. M. (2016). Metode penelitian kuantitatif, kualitatif $\mathcal{E}$ penelitian 